\title{
PERANAN PEMERINTAH DALAM PENERTIBAN PENAMBANGAN ILEGAL NIKEL DI KABUPATEN KOLAKA UTARA
}

\author{
Aslam $^{1}$ Abd. Kadir Adys ${ }^{1}$, Rudi Hardi ${ }^{1}$ \\ 1Program Studi Ilmu Pemerintahan Fakultas Ilmu Ssosial dan Ilmu Politik \\ Universitas Muhammadiyah Makassar \\ Jl Sultan Alauddin No 259 Makassar 90221 \\ Telp. 0411-866972 ext. 107. Fax. 0411-8655888 \\ aslamkolaka@gmail.com, kadir adys@yahoo.co.id, rudi hardi@gmail.com
}

\begin{abstract}
This study discusses the role of government in curbing illegal mining of nickel in North Kolaka. The method used in this study is a qualitative description of the approach. Data collection techniques in this research is observation, interview and documentation. The results showed that: The government's role in the nickel curb illegal mining of all functions is still very weak both in setting / regulation, services, community development, asset management functions of State and public safety, order, security, and protection; Inhibiting factors for the Government to curb illegal mining namely: lack of government coordination, no oversight, public apathy and lack of awareness of the mine owners. The factors supporting government's role in curbing illegal mining nickel miner and openness is the attitude of the community greatly assist the government.
\end{abstract}

Keywords: nickel mining, demolition of illegal miners

\begin{abstract}
ABSTRAK
Penelitian ini membahas tentang peran pemerintah dalam menertibkan pertambangan ilegal nikel di Kabupaten Kolaka Utara. Metode yang digunakan dalam penelitian ini adalah pendekatan deskripsi kualitatif. Teknik pengumpulan data dalam penelitian ini adalah observasi, wawancara mendalam dan dokumentasi. Hasil penelitian menunjukkan bahwa: Peran pemerintah dalam menertibkan pertambangan nikel illegal dari semua fungsi masih sangat lemah baik dalam pengaturan/regulasi, pelayanan, pemberdayaan masyarakat, pengelolaan asset Negara maupun dari fungsi keamanan, ketertiban, pengamanan, dan perlindungan; Faktor penghambat bagi pemerintah dalam menertibkan pertambangan illegal yakni: tidak adanya koordinasi pemerintah, tidak ada pengawasan, sikap apatis masyarakat serta kurangnya kesadaran pemilik tambang. Sedangkan faktor pendukung peran pemerintah dalam penertiban pertambangan nikel illegal adalah sikap penambang dan keterbukaan masyarakat sangat membantu pemerintah.
\end{abstract}

Kata kunci: pertambangan nikel, penertiban penambang illegal 


\section{A. PENDAHULUAN}

Banyak daerah otonom kini tidak sepenuhnya bersifat reaksioner. Kebijakan otonomi daerah di Indonesia diwarnai arogansi pemerintah dalam memuat perda tindakan eksploitatif terhadap sumber daya dan demi penimbunan PAD serta ketimpangan antar daerah berdasarkan polarisasi kaya-miskin kini sedikit banyak mulai memiliki alternatif bentuk aplikasi yang terencana, inovatif, dan tentunya reformis. Jumlahnya tidak banyak, memang, tetapi taksiran awal sebanyak hanya $5 \%$ dari seluruh kabupaten/kota dan propinsi di Indonesia yang berinovasi serta melaksanakan reformasi birokrasi.

Peran pemerintahan pada umumnya berupa penyediaan pelayanan umum, pengaturan dan perlindungan masyarakat serta pembangunan dan pengembangan. Sedangkan tugas dan fungsi pemerintah adalah membuat regulasi tentang pelayanan umum, pengembangan sumber daya produktif, melindungi ketentraman dan ketertiban masyarakat, pelestarian nilai-nilai sosiokultural, kesatuan dan pencapaian keadilan dan pemerataan, pelestarian lingkungan hidup, penerapan dan penegakan peraturan perundangundangan, mendukung pembangunan nasional dan mengembangkan kehidupan berbangsa, bernegara dan bermasyarakat berdasarkan Pancasila serta menjaga tegak, lestari dan utuhnya Negara Republik Indonesia.

Dilihat dari fungsi dan tugas pemerintah maka dalam mengoptimalkan penyelenggaraannya diperlukan penerapan good governance sebagai suatu tata pemerintahan yang baik yang di dalam pelaksanaannya didukung tiga pilar utama yakni pemerintah, masyarakat, dan swasta. Prinsip tersebut dijabarkan sebagai berikut: akuntabilitas, yaitu penyelenggaraan fungsi-fungsi

pemerintah harus dapat dipertanggung jawabkan. Transparansi, dalam penyelenggaraannya, fungsi-fungsi pemerintahan harus memiliki mekanisme yang jelas dan diinformasikan kepada semua pihak.

Keterbukaan, dalam penyelenggaraannya, pemerintahan harus bersifat terbuka sehingga dapat menerima saran dan kritik dari pihak lain guna memperbaiki penyelenggaraan fungsifungsinya.

Rule of law, pemerintahan diselenggarakan dengan menegakkan peraturan dan perundang-undangan yang ada, menegakkan peraturan dan perundangan yang ada. Demokrasi dan Partisipasi, fungsi-fungsi pemerintahan diselenggarakan tanpa mengabaikan kepentingan bersama serta melibatkan masyarakat dan pihak swasta sebagaian dari pilar utama kekuatan negara dalam penyelenggaraan pemerintahan. Kapabilitas berkaitan dengan fungsifungsi pemerintahan harus didukung oleh sumber daya manusia yang terlihat dalam pemerintahan harus mampu memisahkan kepentingan pribadi dan golongan dengang tugas-tugas kenegaraannya.

Responsif, penyelenggaraan pemerintahan harus mampu memenuhi kebutuhan masyarakat dalam kehidupan berbangsa dan bernegara dengan memanfaatkan fasilitas dengan kapasitas yang ada digunakan secara optimal.

Dalam rangka mewujudkan kepentingan nasional, tujuan nasional dan good governance, maka salah satu fungsi pemerintahan yang perlu diterapkan secara utuh adalah pelestarian lingkungan hidup sebagai salah satu upaya untuk menjaga sumber daya alam yang ada agar terhindar dari tangan-tangan jahil manusia yang hanya mampu merusak tanpa melestarikan kekayaan alam yang melimpah, 
misalnya saja dengan adanya aktivitas penambangan liar yang memberi dampak negatif pada lingkungan masyarakat.

Aktivitas penambangan liar apabila dibiarkan terus menerus akan menjadi ancaman bagi kelestarian alam yang dapat menimbulkan bencana di daerah tersebut. Pada dasarnya, pertambangan yang dikelola dengan baik memperhatikan sumber daya alam dan lingkungan akan mewujudkan kemakmuran serta manfaat pada masa sekarang dan masa yang akan datang. Akan tetapi pengelolaan pertambangan saat ini lebih mengutamakan keuntungan secara ekonomi sebesarbesarnya, yang di lain pihak kurang memperhatikan aspek sosial dan lingkungan hidup.

Salah satu akibat penambangan adalah tanah yang tidak dapat kembali seperti semula walaupun telah dilakukan reklamasi, namun lahan tersebut sulit untuk bisa ditanami lagi dengan tumbuh-tumbuhan karena sumber daya tanah tersebut sudah tidak ada lagi, tanah menjadi tidak subur. Dampaknya kepada tanah yang gundul jika kena hujan akan rawan terjadi longsor dan banjir yang mana masyarakat sendirilah yang mengalami kerugian.

Sekelumit

pertambangan dan lingkungan, menunjukkan adanya kegiatan pertambangan sangat rentan dengan rusaknya lingkungan apabila pelakunya tidak dapat mengelola dengan baik lingkungan yang ada disekitarnya. Oleh karena itu, dibutuhkan peran pemerintah dalam hal ini untuk mencegah sebelum kerusakan alam terjadi.

Dampak pertambangan liar ini juga dirasakan masyarakat di Kecamatan Batu Putih Kolaka Utara, dengan adanya pertambangan liar mengakibatkan kerusakan terhadap lingkungan diantaranya kerusakan hutan, pencemaran perairan, dan pendangkalan teluk. Hal ini karena tidak adanya upaya untuk menjaga kelestarian lingkungan. Tidak hanya itu, pertambangan liar di batu putih juga berdampak pada kesehatan karena terjadi pencemaran yang menjadikan lingkungan masyarakat tidak sehat.

Pemerintah sebagai pengelola sumber daya alam di Indonesia sekaligus sebagai pengatur dan pengaman, belum berperan sebagaimana mestinya hal ini dikarenakan pemerintah lamban dalam mengatasi munculnya pertambangan liar di kecamatan Batu Putih. Pemerintah seharusnya memberi pelayanan kepada masyarakat dengan melakukan pemberdayaan khususnya dalam bidang pertambangan.

Berdasarkan masalah tersebut diatas, penulis merasa tertarik untuk meneliti mengenai "Peranan Pemerintah dalam penertiban penambangan illegal nikel di Kecamatan Batu Putih Kabupaten Kolaka Utara“.

\section{B. KERANGKA KONSEP}

Berbagai kalangan mendefinisikan peran yang berbeda satu sama lain meski dalam pengaplikasiannya definisi tersebut dapat dijadikan referensi. Adapun peran menurut Ralph Linton tentang definisi peran adalah sebagai sebuah rangkaian konsep yang berkaitan dengan apa yang dapat dilakukan oleh individu di dalam masyarakat yang berfungsi sebagai organisasi.

Selanjutnya Peran merupakan suatu perilaku yang penting bagi struktur sosial (Soekamto, 1983: 146). Sedangkan menurut Biddle dan Thomas, mendefinisikan peran sebagai: "Serangkaian rumusan yang membatasi perilaku-perilaku yang diharapkan dari pemegang kedudukan tertentu 
(Sarwono, 1991: 243)”. Ada pula yang mendefinisikan peran sebagai "sesuatu yang menjadi bagian atau yang memegang pimpinan yang terutama terjadi dalam suatu hal atau peristiwa (Purwanto,1994)". Melihat dari definisi diatas, dapat dikatakan bahwa peran yang dijalankan oleh seorang individu ataupun kelompok merupakan suatu cermin dari sebuah harapan dan tujuan yang akan dicapai terhadap perubahan perilaku yang menyertainya.

Berhubungan dengan program promosi kesehatan yang dijalankan pemerintah adalah sebuah program yang meningkatkan kesadaran masyarakat tentang pentingnya berperilaku hidup bersih dan sehat (PHBS) sebagai hal paling utama dalam menjaga kesehatan diri dan lingkungan. Akan tetapi program promosi PHBS ini tidak akan berjalan jika tidak adanya peranan dari tokoh masyarakat ataupun kelompok yang ada di dalamnya.

Peranan merupakan suatu konsep mengenai hal ikhwal yang dilakukan oleh individu dan masyarakat sebagai suatu rangkaian organisasi. Livinson mengemukakan bahwa peran mengandung 3 hal penting yaitu (dalam Soekamto, 1983: 95): (1) Peran meliputi norma-norma yang dihubungkan dengan posisi atau kedudukan seseorang dalam kehidupan bermasyarakat atau instansi; (2) Peran adalah suatu konsep tentang apa yang dapat dilakukan oleh individudalam masyarakat atau instansi sebagaoi organisasinya; dan (3) Peran juga dapat dimaknai sebagai perilaku individu yang sangat penting bagi struktur sosial dalam masyarakat atau sebuah instansi. Peranan adalah suatu tugas utama yang dilakukan oleh individu ataupun organisasi sebagai bagian dalam kehidupan bermasyarakat guna mewujudkan cita-cita dan tujuan hidup sehat bersama.
Peran juga dapat dilihat dari partisipasi seseorang atau organisasi terhadap lingkungan sosial dimana ia berada. Seseorang yang beradadi dalam masyarakat adalah individu ataupun kelompok yang mempunyai peran penting dalam keberhasilan program promosi PHBS. Karena mereka selain berfungsi sebagai komunikasi dan edukasi juga merupakan sumber informasi bagi khalayak masyarakat. Peran mereka itu merupakan sesuatu yang diharapkan dan apa yang dilakukan oleh seseorang maupun organisasi terhadap kehidupan sosial yang berada di lingkungan sekitarnya. Peran dalam sosiologi dibahas ketika mengkaji struktur sosial. Dalam struktur sosial ini dikenal dengan dua macam konsep yang sangat penting dalam peran, yaitu status (status) dan peran (role).

Peranan pemerintah adalah suatu perbuatan/ kegiatan pemerintah atas sesuatu pekerjaan dari suatu kedudukan (status) mengenai tugas dan kewajiban serta fungsi pemerintah di dalam masyarakat sebagai suatu organisasi. Dalam hal pertambangan, pemerintah memiliki peranan yang sangat penting diantaranya membuat peraturan pemerintah mengenai izin pertambangan, mengatur wilayah pertambangan serta berhak untuk menertibkan pertambangan liar yang memberi dampak negatif kepada masyarakat di lingkungan pertambangan. (Dyahwanti, 2007).

Lebih lanjut pertambangan merupakan kegiatan, teknologi, dan bisnis yang berkaitan dengan industri pertambangan mulai dari prospeksi, eksplorasi, evaluasi, penambangan, pengolahan, pemurnian, pengangkutan, sampai pemasaran. Pertambangan adalah rangkaian kegiatan dalam rangka upaya pencarian, penambangan (penggalian), pengolahan, pemanfaatan 
dan penjualan bahan galian (mineral, batubara, panas bumi, migas). Selain itu, Pertambangan adalah salah satu jenis kegiatan yang melakukan ekstraksi mineral dan bahan tambang lainnya dari dalam bumi. Penambangan adalah proses pengambilan material yang dapat diekstraksi dari dalam bumi. Tambang adalah tempat terjadinya kegiatan penambangan. (Iskandar, 2010)

Pertambangan liar atau Pertambangan tanpa izin adalah ilegal karena di sebagian besar negara, sumber daya mineral bawah tanah adalah milik negara. Karenanya, sumber daya alam tersebut hanya bisa ditambang oleh operator berlisensi menurut hukum dan peraturan yang ditetapkan oleh pemerintah. (Dyahwanti, 2007)

Pertambangan yang paling ilegal terjadi di daerah pedalaman atau situs pertambangan yang ditinggalkan. Rendahnya produktivitas dan produksi yang terbatas adalah karakteristik utama pertambangan ilegal. Namun demikian, ukuran negara dan frekuensi fenomena tersebut dapat mengubah mikro-produksi ini menjadi bagian yang terlihat jelas pada tingkat produksi nasional. (Dyahwanti, 2007)

Adapun dampak yang terjadi akibat pertambangan liar tersebut diantaranya berkurangnya sumber keseimbangan alam seperti hutan, air dan tanah yang subur sebagian besar disebabkan oleh kegiatan pertambangan yang menghasilkan polutan yang sangat besar sejak awal eksploitasi sampai proses produksi dan hanya mementingkan keuntungan pribadi tanpa memperhatikan faktor kelestarian lingkungan. (Supramono, 2012).

Faktor-faktor yang harus diperhatikan dalam pengolahan penambangan (Dyahwanti, 2007), antara lain:
1) Penentuan Kelayakan Penambangan Aspek penggunaan lahan pada dan di suatu lokasi deposit bahan tambang: dalam rangka harmonisasi pemanfaatan ruang, sebelum bahan tambang diusulkan untuk ditambang, maka perlu diperhatikan terlebih dahulu peruntukan lahan dimana bahan tambang tersebut berada. Apabila terletak pada peruntukan lahan yang berdasarkan peraturan perundangundangan ataupun fungsinya tidak boleh untuk kawasan budi daya, maka bahan tambang tersebut tidak boleh/tidak layak untuk ditambang.

2) Geologi:

Kajian aspek geologi dilakukan setelah selesai kegiatan eksplorasi bahan tambang dimana jenis, sebaran, kuantitas dan kualitasnya sudah diketahui.

3) Sosial ekonomi dan budaya (Sosekbud)

Kajian ini antara lain meliputi jumlah dan letak pemukiman penduduk di sekitar lokasi penambangan, adatistiadat dan cagar/situs budaya (termasuk daerah yang dikeramatkan).

Faktor lain yang tidak kalah penting adalah mengenai lokasi pengolahan penambangan. Berikut merupakan hal yang harus diperhatikan dalam pemilihan lokasi penambangan (Dyahwanti, 2007), antara lain: (1) Lokasi penambangan sedapat mungkin tidak terletak pada daerah resapan atau pada akuifer sehingga tidak akan mengganggu kelestarian air tanah di daerah sekitarnya; (2) Lokasi penambangan sebaiknya terletak agak jauh dari pemukiman penduduk sehingga suara bising ataupun debu yang timbul akibat kegiatan penambangan tidak akan mengganggu penduduk; dan (3) Lokasi penambangan tidak berdekatan dengan mata air penting sehingga tidak akan mengganggu kualitas maupun kuantitas 
air dari mata air tersebut, juga untuk menghindari hilangnya mata air.

$$
\text { Pada dasarnya industri }
$$

pertambangan memiliki hasil yang maksimal jika dilihat dari energi yang dihasilkan. Namun banyak sekali dampak-dampak yang dapat menyebabkan terjadinya kerusakan lingkungan. Oleh karena itu, perlu dilakukan proses pertambangan yang sesuai prosedur dan terencana dengan baik sehingga selain didapatkan hasil yang maksimal, kelestarian alam pun dapat terjaga. Selain itu juga diperlukan energi alternatif untuk mengurangi kebutuhan akan hasil tambang.

Adapun Regulasi terkait pertambangan di Indonesia adalah sebagai berikut Peraturan Menteri Energi Sumber Daya Mineral tentang Kegiatan Pengolahan dan Pemurnian Mineral adalah untuk melaksanakan ketentuan Pasal 96 dan Pasal 111 Peraturan Pemerintah Nomor 23 Tahun 2010 tentang Pelaksanaan Kegiatan Usaha Pertambangan Mineral dan Batubara sebagaimana telah diubah dengan Peraturan Pemerintah Nomor 24 Tahun 2012 tentang Perubahan Atas Peraturan Pemerintah Nomor 23 Tahun 2010 Tentang Pelaksanaan Kegiatan Usaha Pertambangan Mineral dan Batubara (PP tentang Pelaksanaan Kegiatan Usaha Pertambangan Minerba).

Peraturan menteri ESDM tentang kegiatan pengolahan dan pemurnian mineral berdasarkan Pasal 2 ayat (1) yaitu golongan komoditas tambang mineral yang dapat ditingkatkan nilai tambahnya adalah: (1) Mineral logam; (2) Mineral bukan logam; atau (3) Satuan.

Selanjutnya, di dalam Pasal 3 ayat (1) Permen ESDM tentang Kegiatan Pengolahan dan Pemurnian Mineral diatur bahwa peningkatan nilai tambah komoditas tambang dilaksanakan melalui kegiatan: (1) pengolahan dan/atau pemurnian untuk komoditas tambang mineral logam tertentu; (2) pengolahan untuk komoditas tambang mineral bukan logam tertentu; dan (3) pengolahan untuk komoditas tambang batuan tertentu.

Adapun kegiatan pengolahan dan/atau pemurnian sebagaimana dimaksud di atas ditetapkan batasan minimum pengolahan dan/atau pemurnian berdasarkan atas pertimbangan sebagai berikut: (1) Memiliki sumber daya dan cadangan bijih dalam jumlah besar; (2) Untuk mendorong peningkatan kapasitas produksi logam di dalam negeri; (3) Teknologi pengolahan dan/atau pemurnian sudah pada tahap teruji; (4) Produk akhir pengolahan dan/atau pemurnian sebagai bahan baku industri kimia dan pupuk dalam negeri; (5) Produk akhir sampingan hasil pengolahan dan/atau pemurnian untuk bahan baku industri kimia dan pupuk dalam negeri; (6) Sebagai bahan baku industri strategis dalam negeri yang berbasis mineral; (7) Memberikan efek ganda baik secara ekonomi dan negara; dan/atau (8) Untuk meningkatkan penerimaan Negara.

Setiap jenis komoditas tambang mineral logam tertentu, mineral bukan logam dan batuan tertentu wajib diolah dengan batasan minimum pengolahan yang telah ditetapkan di dalam lampiran I, II dan III Peraturan menteri ESDM tentang Kegiatan Pengolahan dan Pemurnian Mineral. Pemegang Ijin Usaha Pertambangan (IUP) Operasi Produksi mineral logam dan Ijin Usaha Pertambangan Khusus (IUPK Operasi Produksi mineral logam wajib melakukan pengolahan dan/atau pemurnian hasil penambangan di dalam negeri untuk komoditas tambang mineral logam. 
Pemegang IUP Operasi Produksi mineral bukan logam dan batuan juga wajib melakukan pengolahan hasil penambangan di dalam Negeri untuk komoditas tambang mineral bukan logam dan batuan. Jika pemegang IUP Operasi Produksi dan IUPK operasi produksi tidak ekonomis untuk melakukan sendiri pengolahan dan/atau pemurnian mineral, maka dapat melakukan kerja sama pengolahan dan/atau pemurnian dengan pihak lain yang memiliki IUP operasi produksi, IUPK operasi produksi, atau IUP operasi produksi khusus untuk pengolahan dan/atau pemurnian.

Kerja sama pengolahan dan/atau pemurnian ini dapat berupa jual beli bijih atau konsentrat, kegiatan untuk melakukan proses pengolahan dan/atau pemurnian, atau pembangunan bersama sarana dan prasarana pengolahan dan/atau pemurnian. Rencana kerja sama pengolahan dan/atau pemurnian tersebut hanya dapat dilaksanakan setelah mendapatkan persetujuan dari Direktur Jenderal atas nama Menteri pertambangan mineral sebagaimana disebutkan pada Pasal 8 Permen ESDM tentang Kegiatan Pengolahan dan Pemurnian Mineral.

Pertambangan liar di Batu Putih mempunyai beberapa karakteristik, yaitu tidak dapat diperbarui (nonreneweble), mempunyai resiko relatif lebih tinggi, dan pengusahaannya mempunyai dampak lingkungan baik fisik maupun sosial yang relatif lebih tinggi dibandingkan pengusahaan komoditi lain pada umumnya. Karena mereka melakukan penambangan nikel yang pada dasarnya, sifatnya yang tidak dapat diperbaharui tersebut pengusaha pertambangan selalu mencari cadangan yang terbukti (proven reserves) baru (Dirhamsyah, 2012).
Hal lain yang masih dipertentangkan adalah berapa bagian keuntungan pemerintah Batu putih dari usaha pertambangan tersebut. Penjelasan dari pemerintah mengenai kontrak pertambangan nikel (tertuma mengenai pembangian keuntungannya) yang berlaku di Indonesia, perbandingan kontrak tersebut dengan yang berlaku Negara-Negara lain, keuntungan (rate of return) rata-rata usaha tersebut di Indonesia perlu diberikan untuk mengetahui apakah keuntungan pemerintah tersebut memadai atau tidak. Mungkin perlu juga di pikirkan kebijakan pajak yang berbeda untuk ukuran cadangan yang berbeda karena keuntungannya pun berbeda. Perlu dicatat bahwa beberapa Negara memperlakukan kontrak pertambangan yang berbeda bagi BUMN, swasta nasional, dan swasta asing. Akan lebih baik lagi apabila imformasi tersebut di sertai dengan biaya pengusahaan pertambangan untuk berbagai kondisi tambang terutama yang terjadi terhadap pengelolaan pertambangan di Kabupaten Kolaka Utara.

Dasar kebijakan publik di bidang pertambangan Kabupaten Kolaka Utara adalah Undang-undang 1945 Pasal 33 Ayat (3) yang menyatakan bahwa bumi dan air dan kekayaan alam yang terkandung di dalamnya dikuasi oleh Negara dan digunakan sebesarbesarnya untuk kemakmuran rakyat. Dalam pelaksanaannya mungkin dapat dipertimbangkan hal-hal berikut ini:

1) Kita baru akan mengundang perusahaan asing apabila bangsa Indonesia tidak berani mengambil resiko atau tidak menguasai tekhnologi untuk bidang pertambangan tersebut. Alasannya, apabila dana tersebut dikeluarkan oleh pengusaha asing, tentunya dana tersebut akan kembali ke 
Negara dimana pengusaha tersebut berasal, tetapi akan lebih menguntungkan apabila dikerjakan oleh pengusaha Lokal;

2) Apabila resikonya tidak besar, serta teknoginya dikuasai dan permasalahannya hanya modal, sebagian pendapatan pemerintah dari sektor pertambangan umum yang sudah memberikan keuntungan banyak (misal: batu bara). Pendapatan tersebut dapat digunakan untuk ekplorasi dan investasi pada sektor-sektor pertambangan lainnya. Hal yang sama dapat di perlakukan untuk migas, sehingga sebagian pendapatan pemerintah dari migas dapat digunakan untuk eksplorasi dan investasi untuk energi lain yang lebih bersih lingkungan, seperti pasan bumi dan tenaga air. Sebagai perbandingan, pada sektor kehutanan terdapat dana reboisasi;

3) Aspek lingkungan baik fisik maupun sosial harus di pertimbangkan dalam setiap kontrak pertambangan dan pengusaha pertambangan harus menyediakan biaya untuk mengatasi permasalahan lingkungan tersebut;

4) Investor yang serius menginginkan peraturan yang jelas dan di jalankan secara konsisten di seluruh sektor. Investor yang serius menginginkan adanya kebijakan lingkungan hidup, keselamatan, dan kesehatan kerja yang jelas, konsisten, dan realistis. Ini tercermin dalam berbagai peraturan yang dapat di terapkan. Tidak adanya persyaratan lingkungan hidup yang kelas membuat para investor sulit mendapatkan dana di pasar modal internasional. Hal tersebut juga akan membuat investor harus menerima kritik karena di anggap tidak menjalankan tanggung jawab dengan baik.

Kinerja yang buruk dari aktivitas penambangan liar di Kecamatan Batu Putih akan membuat seluruh sektor mendapat kecaman. Kementerian lingkungan hidup memegang peranan penting dalam memperkuat pelaksanaan prosedur analisis mengenai dampak lingkungan (AMDAL) dan menerapkan aturan yang lebih ketat bagi pertambangan liar yang tidak menjalankan AMDAL.

Desentralisasi

dapat memperlemah perlindungan atas lingkungan hidup. Salah satu masalah penting dalam desentralisasi adalah bagaimana melaksanakan pengawasan aspek lingkungan hidup.

\section{METODE PENELITIAN}

Penelitian ini dilaksanakan di Kecamatan Batu Putih Kabupaten Kolaka utara mengingat peran pemerintah dalam penertiban aktivitas pertambangan liar di daerah tersebut adalah keinginan terbesar masyarakat sekitar. Jenis Penelitian yang digunakan adalah penelitian deskriptif kualitatif yakni suatu bentuk penelitian yang bertujuan untuk memberikan gambaran umun berbagai macam data yang di kumpulkan dari lapangan secara objektif berkaitan dengan objek penelitian tentang peran pemerintah dalam penertiban aktivitas pertambangan liar di kecamatan batu putih kabupaten Kolaka Utara. Teknik pengumpulan data yang digunakan adalah Teknik Observasi adalah suatu teknik pengumpulan data yang di lakukan oleh peneliti untuk melakukan pengamatan langsung terhadap peran pemerintah yang dilakukan di lokasi pertambangan liar.

Teknik wawancara adalah suatu teknik pengumpulan data yang di lakukan peneliti dengan cara melakukan 
wawancara kepada pejabat pemerintahan di Kecamatan Batu Putih serta warga yang berada di sekitar lokasi penambangan liar. Dokumentasi adalah teknik pengumpulan data yang dilakukan peneliti dengan cara mengambil gambar di tempat penelitian. Jenis data penelitian ini adalah deskriptif kualitatif yaitu data berupa laporan yang berbentuk kata, kalimat, skema, dan gambar yang dijadikan dasar dalam memecahkan permasalahan yang ada. Sumber data penelitian ini adalah Data Primer, yaitu data hasil penelitian yang diperoleh melalui wawancara dan pengamatan langsung terhadap objek yang diteliti. Data sekunder, yaitu data yang diperoleh dari sumber lain, dari dokumen dan bahan bacaan lainnya yang berhubungan dengan obyek penelitian. Proses analisis data di lakukan bertahap sebagai berikut Proses analisis data di mulai dengan menelaah seluruh data yang tersedia dari hsil wawancara mendalam, pengamatan (observasi) dan catatan lapangan. Mereduksi data dengan cara membuat rangkuman (inti dan proses pernyataan dari informasi). Ada beberapa usaha yang dilakukan peneliti untuk memperoleh keabsahan temuannya yakni Triangulasi waktu peneliti merupakan instrumen utama penelitian, semakin lama peneliti terlibat dalam pengumpulan data, akan semakin memungkinakan meningkatnya derajat kepercayaan data yang dikumpulkan.

\section{HASIL DAN PEMBAHASAN}

\section{Peran Pemerintah dalam Menertibkan Aktivitas Penambang Liar Di Kecamatan Batu Putih Kabupaten Kolaka Utara}

Hubungan antara pemerintah daerah dan perusahaan pertambangan merupakan hubungan kerja yang kedudukannya perusahaan pertambangan berada di bawah naungan pemerintah dan bersifat kemitraan. Kedudukan tersebut bermakna bahwa pemerintah itu memiliki kedudukan di atas perusahaan pertambangan dengan kata lain pemerintah adalah atasan dan penambang adalah bawahan. Hal ini tercermin dalam usaha pemerintah untuk menertibkan penambang liar yang ada di kecamatan Batu Putih Kabupaten Kolaka Utara.

Meskipun memiliki Hubungan kemitraan, akan tetapi perusahaan pertambangan harus mengikuti aturan yang telah ditetapkan oleh pemerintah. Terlebih dengan adanya penambang ilegal yang menjamur dikawasan pertambangan di daerah tersebut. Hal ini menimbulkan pertanyaan yang besar, mengapa penambang liar dapat beroperasi dikawasan pertambangan dengan bebasnya. Antara pemerintah dan perusahaan pertambangan sudah tentu menjalin sebuah hubungan kerja sama yang saling menguntungkan sehingga mereka menjadi berkawan yang seharusnya pemerintah memerangi penambang ilegal. Melihat hubungan kerja sama dengan pemerintah bukan tidak mungkin mereka dapat bertindak semaunya, dengan kata lain ada kongkalikong dengan penambang ilegal tersebut. Meskipun demikian, pemerintah sesungguhnya memiliki peranan penting dalam usaha menertibkan pertambangan nikel ilegal.

Peran pemerintah yang dimaksud merupakan fungsi pemerintah dalam menjalankan tugasnya. Fungsi tersebut adalah fungsi pengaturan/regulasi, fungsi pelayanan kepada masyarakat, fungsi pemberdayaan masyarakat, fungsi pengelolaan asset/kekayaan Negara serta fungsi Keamanan, 
Ketertiban, Pengamanan dan Perlindungan (Polisional).

1) Fungsi Pengaturan/Regulasi

$$
\text { Fungsi pengaturan/regulasi }
$$

(penetapan kebijakan publik/Negara) adalah fungsi yang tak dapat didelegasikan dipindahkan ataupun diprivatisasikan kepada organisasi atau lembaga di luar pemerintahan. Kebijakan tersebut dapat berupa tertulis dan tidak tertulis, kebijakan-kebijakan pemerintahan Negara perlu dirumuskan secara tertulis dengan mengikuti suatu "national legal drafting system and process" dan dituangkan dalam aturan perundang-undangan yang tepat sehingga memiliki kekuatan dan kepastian hukum serta jelas keterkaitan dan keserasiannya satu sama lain, dan dapat dipertanggungjawabkan di hadapan pemegang kedaulatan rakyat. Pemerintah daerah di tingkat kecamatan Batu Putih Kabupaten Kolaka Utara berperan penting dalam pengaturan kebijakan yang berlaku dalam kehidupan bermasyarakat tak terkecuali di bidang pertambangan yang merupakan salah satu sumber penghidupan masyarakat Batu Putih. Adapun wawancara dengan camat di Kantor Kecamatan Batu putih tentang keberadaan penembang nikel yang hasilnya sebagai berikut:

"keberadaan tambang nikel di daerah ini memang benar adanya, lokasinya ada di beberapa tempat, karena memang di kecamatan Batu putih ini banyak mengandung nikel" (wawancara Z).

Sesuai dengan kutipan hasil wawancara di atas dapat dilihat bahwa di Kecamatan Batu Putih terdapat beberapa lokasi penambangan nikel. Hasil wawancara ini sejalan dengan apa yang dibahasakan oleh informan (masyarakat) lainnya bahwa: "yang ku tau saya di kecamatan Batu putih ini banyak memang mengandung nikel, banyak juga mi masuk perusahaan pertambangan disini. tidak jelas yang mana ada izinnya sama yang tidak ada karena banyak ki" (wawancara L).

2) Fungsi Pelayanan Kepada Masyarakat

Menurut Rasyid dalam buku Makna Pemerintahan: Tinjauan dari segi etika dan kepemimpinan (2002), ada tiga fungsi hakiki pemerintah, yaitu pelayanan (Service), pemberdayaan (empowerment) dan pembangunan (development). Fungsi pelayanan yaitu fungsi pemerintah sebagai penyedia jasa-jasa pelayanan public yang tidak diprivatisasikan termasuk jasa Hankam, layanan civil dan layanan birokrasi. Peran pemerintah dalam memberikan pelayanan kepada masyarakat di Kecamatan Batu Putih masih dinilai kurang memuaskan, karena dalam hal pertambangan pengaduan masyarakat mengenai dampak negatif yang ditimbulkan dari pertambangan illegal ini belum mendapatkan respon yang serius dari pemerintah.

3) Fungsi Pemberdayaan Masyarakat

Fungsi pemberdayaan masyarakat adalah fungsi yang berhubungan secara negative dengan kondisi ekonomi, politik dan social warga masrakat, dalam arti: semakin tinggi taraf hidup warga masyarakat, semakin kuat posisi tawar (bargaining position) dan semakin integrative masyarakat. Pemberdayaan harus terus menerus, komperhensif dan simultan, sampai ambang batas tercapainya keseimbangan yang dinamik antara pemerintah dan warga masyarakat. Dalam usaha meningkatkan kesejahteraan masyarakat, salah satu cara yang dapat ditempuh oleh pemerintah adalah dengan melakukan 
pemberdayaan masyarakat. Keberadaan tambang nikel di Kecamatan Batu putih merupakan mimpi indah bagi penduduk setempat karena menjadi sumber penghidupan yang sangat menjajikan. Pemerintah pun melakukan pemberdayaan masyarakat dengan membuka lapangan kerja yang luas bagi penduduk yang berada di sekitar lokasi pertambangan.

"seperti yang kita ketahui
pertambangan nikel ini
menjadikan kehidupan kami
lebih meningkat utamanya
dalam sektor ekonomi karena
menjadi mata pencaharian
utama bagi kami, saya senang
karena pemerintah melakukan
usaha untuk memberdayakan
masyarakat yang berada di
sekitar lokasi pertambangan
nikel". (wawancara L).

Pemberdayaan masyarakat yang dilakukan oleh pemerintah mendapat sambutan yang baik, karena mereka yakin hal ini mampu meningkatkan kesejahteraan hidupnya. Jawaban yang sama juga dilontarkan oleh salah satu informan dilokasi pertambangan nikel illegal.

"secara kasat mata memang sudah keliatan ji kalau keberadaannya ini penambang membuka lapangan kerja baru bagi masyarakat jadi secara tidak langsung memang pemerintah melakukan pemberdayaan di bidang pertambangan" (wawancara $A S)$.

4) Fungsi pengelolaan asset/kekayaan Negara

Asset atau kekayaan Negara adalah tak lain merupakan sumber daya (resources) yang terdapat di bumi Indonesia yang merupakan milik bangsa Indonesia yang dikelola/diurus oleh pemerintah. Sumber daya alam dewasa ini sudah menjadi komoditas politik baik di dalam maupun ke luar. Pengelolaan sumber daya adalah penataan barang-barang, baik yang mempunyai manfaat lebih dari setahun (inventaris) maupun barang pakai habis yang diperoleh melalui tahapan: perencanaan kebutuhan, pengadaan, penerimaan/penyimpanan,

pendistribusian, pemeliharaan, penghapusan / pelelangan, pengawasan, evaluasi dan pelaporan. Pertambangan nikel di Kecamatan Batu Putih Kabupaten Kolaka Utara merupakan salah satu asset Negara yang tak ternilai harganya.

Oleh karena itu pemerintah hendaknya melakukan pengelolaan atau pengawasan baik terhadap kekayaan Negara tersebut. Sebagai salah satu peranan atau fungsi pemerintah dalam menjalankan tugasnya, pengelolaan asset di wilayah pertambangan nikel di Kecamatan Batu Putih belum terjaga dengan baik. Terbukti dengan adanya penambang liar yang seenaknya melakukan proses pertambangan tanpa izin dan mengabaikan dampak negatif yang dapat ditimbulkan. Berikut petikan wawancara kami dengan salah seorang informan.

"Pertambangan nikel di daerah kami Kecamatan Batu Putih Kabupaten Kolaka Utara memang merupakan asset Negara yang sangat besar oleh karena itu pemerintah harus bisa mengelolahnya dengan baik". (wawancara MA).

Penertiban penambang nikel illegal merupakan salah satu upaya perlindungan terhadap asset Negara, meskipun demikian bukanlah perkara mudah untuk menertibkannya dalam waktu yang singkat karena semua butuh proses yang panjang. Termasuk untuk merebut kembali daerah pertambangan dari tangan manusia yang tidak 
bertanggung jawab yakni penambang nikel liar. Pernyataan informan berikutnya hampir sama dengan hasil wawancara sebelumnya yakni sebagai berikut :

"di daerah kami memang terdapat aset negara yang sangat besar bahkan keberadaan pertambangan nikel ini adalah salah satu yang terbesar di wilayah indonesia bagian timur" (wawancara L).

5) Fungsi keamanan, ketertiban, pengamanan dan perlindungan.

Fungsi pemerintah di bidang pertahanan, keamanan, ketertiban umum, pengamanan dan perlindungan sudah termasuk dan terkait dengan funsi pemerintah di bidang perumusan kebijakan (pengaturan), pelayanan, pemberdayaan, dan fungsi pengelolaan asset/kekayaan negara. Misalnya, fungsi keamanan dan ketertiban umum merupakan tugas aparatur kepolisian (polisional) yang dapat juga dirumuskan sebagai fungsi pelayanan keamanan dan ketertiban umum oleh kepolisian transparansi menunjuk pada suatu keadaan dimana segala aspek dari proses penyelenggaraan pelayanan bersifat terbuka dan dapat diketahui dengan mudah oleh para pengguna Kendaraan Bermotor atau wajib pajak. Jika segala aspek proses penyelenggaraan pelayanan seperti persyaratan, biaya dan waktu yang diperlukan, cara pelayanan, serta hak dan kewajiban penyelenggara dan pengguna layanan dipublikasikan secara terbuka sehingga mudah diakses dan dipahami oleh wajib pajak, maka praktik penyelenggaraan pelayanan itu dapat dinilai memiliki transparansi yang tinggi.

Sebaliknya, kalau sebagian atau semua aspek dari proses penyelenggaraan pelayanan itu tertutup dan informasinya sulit diperoleh oleh wajib pajak, maka penyelenggaraan pelayanan itu tidak memenuhi kaidah transparansi. Usaha untuk menertibkan pertambangan nikel illegal di Kecamatan Batu Putih Kabupaten Kolaka Utara tak lepas dari fungsi atau peranan pemerintah sebagai aparat yang berkewajiban untuk menjaga keamanan, ketertiban, pengamanan dan perlindungan. Pemerintah bekerja sama dengan aparat kepolisian untuk berusaha melakukan penertiban penambangan nikel illegal. Akan tetapi, Informasi yang peneliti dapatkan dari salah seorang penambang menyatakan bahwa :

"pertambangan nikel ilegal ini sudah lama mi, kami juga sudah lama bekerja di sini dan tidak ada itu yang namanya penertiban tambang liar, semua berjalan seperti biasa, tidak ada itu yang namanya rasa khawatir" (wawancara AS).

\section{Faktor Pendukung dan Penghambat Penertiban Aktivitas Penambang Liar Di Kecamatan Batu Putih Kabupaten Kolaka Utara}

Komunikasi pemerintahan dalam pengelolaan tambang nikel di Kecamatan Batu Putih sesuai dengan hasil penelitian yang menunjukkan tidak adanya usaha penertiban sehingga dipastikan masih dominannya variabel penghambat dibandingkan dengan variabel pendukung. Oleh karena itu dalam uraian berikut ini akan dideskripsikan masing-masing variabel penghambat dan pendukung tersebut.

\section{a. Faktor Penghambat}

Faktor-faktor yang menghambat peran pemerintahan dalam menertibkan pertambangan nikel ilegal terdiri atas; koordinasi, ketegasan pemerintah, pengawasan, sikap masyarakat dan kesadaran pemilik tambang. Berikut akan dideskripsikan 
masing-masing faktor penghambat peran pemerintahan dalam menertibkan pertambangan nikel illegal.

1) Koordinasi Pemerintah

Koordinasi yang dimaksud di sini adalah koordinasi internal Pemerintah Kabupaten Kolaka Utara yaitu antara kepala desa, camat dan Dinas Pertambangan Kabupaten kolaka Utara. Kurang terbentuknya komunikasi dalam pengelolaan tambang nikel adalah akibat dari miskomunikasi antara pemerintah di masing-masing level mulai dari level paling rendah dalam hal ini adalah kepala desa dan jajarannya, Camat Batu Putih dan jajarannya maupun Dinas Pertambangan Kabupaten Kolaka Utara. Berikut hasil wawancara dengan salah satu tokoh masyarakat di sekitar pertambangan nikel:

"adanya ini pertambangan nikel illegal dek sebenarnya tidak ada komunikasi secara resmi ini antara kepala desa dengan camat dan juga bupati, buktinya itu kepala desa tidak pernah menyampaikan langsung ke bupati masalah yang timbul akibat adanya pertambangan illegal". (wawancara L).

2) Ketegasan Pemerintah

Hal mendasar yang menghambat pemerintahan dalam penertiban tambang nikel illegal adalah kurangnya ketegasan pemerintah, baik Pemerintah Kabupaten Kolaka Utara, Camat Batu Putih maupun kepala desa masingmasing lokasi penambangan nikel. Tidak adanya ketegasan ini dianggap membentuk komunikasi yang kaku dalam pengelolaan tambang nikel sehingga kegiatan penambangan berlangsung secara terus menerus walaupun tidak memiliki izin. Hal tersebut sesuai dengan hasil wawancara yang telah dilakukan dengan salah satu tokoh masyarakat. "pemerintah memang tidak tegas untuk menertibkan pertambangan liar ini, jadi susah. Ini mi yang menjadikan komunikasi seperti kaku antar aparat pemerintahan". (wawancara $A H$ ).

\section{3) Pengawasan}

Pengawasan yang dimaksud adalah pengawasan yang dilakukan terhadap pengelolaan tambang nikel baik lembaga eksekutif maupun legislatif (DPRD Kabupaten Kolaka Utara). Eksekutif dalam hal ini adalah Pemerintah Kabupaten Kolaka Utara (Dinas Pertambangan Kabupaten Kolaka Utara), Camat Batu Putih dan kepala desa lokasi tambang.

Eksekutif dalam hal ini adalah Pemerintah Kabupaten Kolaka Utara (Dinas Pertambangan Kabupaten Kolaka Utara), Camat Batu Putih dan kepala desa lokasi tambang. Berikut hasil wawancara dengan seorang tokoh masyarakat

"memang kelihatan tidak ada pernah dilakukan pengawasan langsung terhadap perusahaan pertambangan nikel illegal, entah di sengaja atau tidak. Setahu saya juga katanya itu ada permainan antara pemilik tambang sama oknum tertentu jadi bagaimana mau dilakukan pengawasan" (wawancara AH).

\section{b. Faktor Pendukung}

Faktor pendukung peran pemerintahan dalam menertibkan tambang nikel ilegal adalah sikap penambang dan keterbukaan masyarakat. Berikut masing-masing dari faktor pendukung.

1) Sikap Penambang

Sikap penambang yang dimaksud di sini adalah ketersediaan penambang dalam memberikan informasi mengenai 
pengelolaan tambang nikel illegal. Penambang pada umumnya secara terbuka menyampaikan informasi yang dibutuhkan oleh pihak manapun sepanjang tidak merugikan pihak penambang itu sendiri.

"kami sebagai penambang memberikan informasi apa adanya saja tidak ada yang perlu ditutup-tutupi karena saya rasa semua orang tahu yang sebenarnya". (wawancara M).

2) Keterbukaan Masyarakat

Keterbukaan masyarakat di Kecamatan Batu Putih adalah merupakan suatu hal yang mendukung terbentuknya peran pemerintahan dalam pengelolaan pertambangan nikel ilegal. Walaupun pada dasarnya warga memilih pasif dalam mengkomunikasikan pengelolaan tambang nikel ilegal tetapi mereka dapat terbuka menerima keberadaan tambang nikel ilegal tersebut.

"mau bagaimana lagi, adanya pertambangan nikel ini secara langsung juga memberi dampak terhadap kehidupan ekonomi kami jadi dengan senang hati kami menerima keberadaan tambang nikel ini". (wawancara AS)

\section{E. PENUTUP}

Peran pemerintah dalam penertiban pertambangan nikel illegal ini dapat di lihat dari fungsinya. Dalam pengaturan atau regulasi pemerintah masih sangat lemah sebagai penentu kebijakan karena perusahaan pertambangan nikel yang ada tanpa surat izin dari pemerintah. Selain itu pemerintah belum memberikan pelayanan maksimal terhadap pengaduan masyarakat terkait dengan adanya pertambangan nikel ini, meskipun keberadaan perusahaan pertambangan ini dikatakan salah satu wadah untuk memberdayakan masyarakat akan tetapi sebagian besar tambang nikel tersebut tidak lagi dikelolah oleh pemerintah akan tetapi milik pribadi perusahaan pertambangan. Sekalipun tambang nikel illegal ini di sebut sebagai asset negara. Dari segi pengamanan dan penertiban, keberadaan pertambangan nikel illegal ini sulit dilakukan karena adanya kerja sama antara penambang dan oknum tertentu yang memiliki kewenangan dilokasi pertambangan tersebut.

Faktor penghambat peran pemerintah sangat dominan dalam usaha untuk menertibkan pertambangan nikel illegal di kecamatan Batu Putih Kabupaten Kolaka Utara . Adapun faktor penghambat tersebut adalah tidak adanya koordinasi pemerintah, tidak ada pengawasan, sikap apatis masyarakat serta kurangnya kesadaran pemilik tambang. Sedangkan faktor pendukung peran pemerintah dalam penertiban pertambangan nikel illegal adalah sikap penambang dan keterbukaan masyarakat sangat membantu pemerintah.

\section{DAFTAR PUSTAKA}

Dyahwanti. 2007. Intraksi Aktor dalam Pelaksanan pertambangan Liar di Kabupaten Kolaka Utara. Univesitas Negeri Makassar: Skripsi.

Fahmi, Irham. 2011. Manajemen Pengambilan Keputusan. Bandung: Alfabeta.

Ikbar, Yanuar. 2012. Metode Penelitian Sosial Kualitatif. Bandung: PT Refika Aditama. 
Iskandar. 2010. Pertambangan di Indonesia. Jakarta: PT. Rajagrafindo.

Mas oed, Mohtar. 1994. Politik Birokrasi dan Pembangunan. Yogyakarta: diterbitkan oleh Pustaka Pelajar.

Nugroho D, Riant. 2003. Kebijakan Publik Formulasi Implementasi dan Evaluasi. Jakarta: Elekx Media Komputindo.

Nurdjaman, Progo. 2004. Pokok-pokok penyelenggaraan pemerintahan umum. Direktur Jenderal Pemerintahan Umum.

Purwanto. 1994. Peran Pemerintah Kelurahan Dalam Meningkatkan Kesejahteraan Masyarakat Di Kelurahan Mataallo Kecamatan Bajeng Kabupaten Gowa. UNM: Skripsi.

Rewansyah, $\quad$ Asmawi. 2011. Kepemimpinan dalam Pelayanan Publik. Jakarta: STIA-LAN.

Salim. 2012. Hukum Pertambangan di Indonesia. Jakarta: PT Rajagrafindo Persada.

Sarwono. 1991. Pengantar Kebijakan Publik. Jakarta: Rajawali Press.
Soekamto. 1983. Analisis Kebijakan Publik. Yogyakarta: Pustaka Pelajar.

Supramono, Gatot. 2012. Hukum Pertambangan Mineral dan Batubara di Indonesia. Jakarta: PT Rineka Cipta.

Sutedi, Adrian. 2011. Hukum Pertambangan. Jakarta: Sinar Grafika.

Dokumen :

UUD 1945 Pasal 18 Ayat (2), Pasal 33 ayat (3)

Undang-undang Nomor. 32 Tahun 2004 tentang Pemerintah Daerah

Peraturan Pemerintah Nomor. 38 Tahun 2007 tentang Pembagian Urusan Pemerintahan antara pemerintah

Peraturan Pemerintah Nomor. 41 Tahun 2007 tentang Organisasi Perangkat Daerah

Peraturan Mentri Nomor. 24 Tahun 2012 tentang Perubahan Atas Peraturan Pemerintah

Peraturan Mentri Nomor. 23 Tahun 2010 tentang Pelaksanaan Kegiatan Usaha Pertambangan Mineral dan Batubara

Peraturan Mentri Nomor. 7 Tahun 2012 tentang Ijin Perijinan Rakyat (IPR) 